\begin{tabular}{|l|l|}
\hline $\begin{array}{l}\text { 2. To: (Receiving organization) } \\
\text { Distribution }\end{array}$ & $\begin{array}{l}\text { 3. From: (Originating Organization) } \\
\text { Retrieval Engineering }\end{array}$ \\
\hline 5. Proj./Prog./Dept./Div.: & $\begin{array}{l}\text { 6. Design Authority/ Design Agent/Cog. } \\
\text { Engr.: } \quad \text { T. W. Staehr }\end{array}$ \\
AZ-101 Mixer Pump Test & \multicolumn{2}{l}{}
\end{tabular}

8. Originator Remarks:

This EDT is for document review.

11. Receiver Remarks: 11A. Design 8aseline Document? [] Yes [X] No
4. Related EDT No.:

7. Purchase Order No.:

NA

9. Equip./Component No.:

Ultrasonic Interface Level Analyzer

10. System/Bldg./Facility: 241-AZ

12. Major Assm. Owg. No.:

$\mathrm{H}-14-100454$

13. Permit/Permit Application No.: NA

14. Required Response Date: March 10, 1999

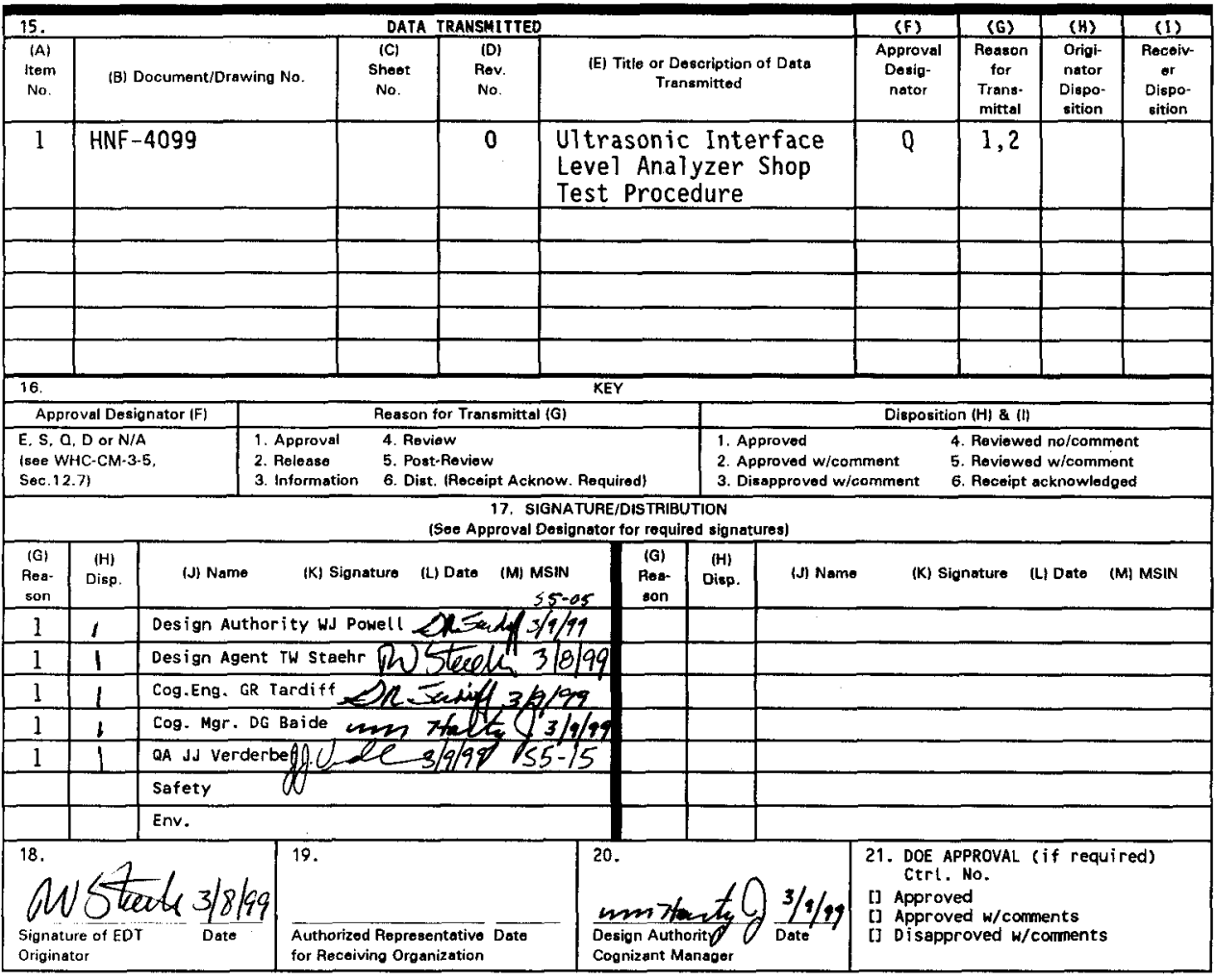




\section{Ultrasonic Interface Level Analyzer Shop Test Procedure}

T. W. Staehr

COGEMA Engineering Corporation, Richland, WA 99352

U.S. Department of Energy Contract DE-AC06-96RL13200

EDT/ECN: EDT-626561

Org Code: 82400

B\&R Code: EW3130010 Total Pages: 16

UC: 2030

Charge Code: 106846

Key Words: Ultrasonic. Interface, instrument, shop test, AZ-101. tank

Abstract: The Ultrasonic Interface Level Analyzer (URSILLA) instrument is planned to be installed in the AZ-101 tank to measure sludge interface levels during mixer pump testing. The URSILLA uses an ultrasonic ranging technique (SONAR) to measure the sludge interfaces. The purpose of this test is to provide a documented means of verifying that the functional components of the URSILLA operate properly.

TRADEMARK DISCLAIMER. Reference herein to any specific commercial product, process, or service by trade name, tradenark, manufacturer, or otherwise, does not necessarily constitute or imply its endorsement, reconmendation, or favoring by the United States Government or any agency thereof or its contractors or subcontractors.

Printed in the United States of America. To obtain copies of this document, contact: Document control Services, P.0. Box 950, Mailstop H6-08, Richland WA 99352, Phone (509) 372-2420;

Fax (509) 376-4989.
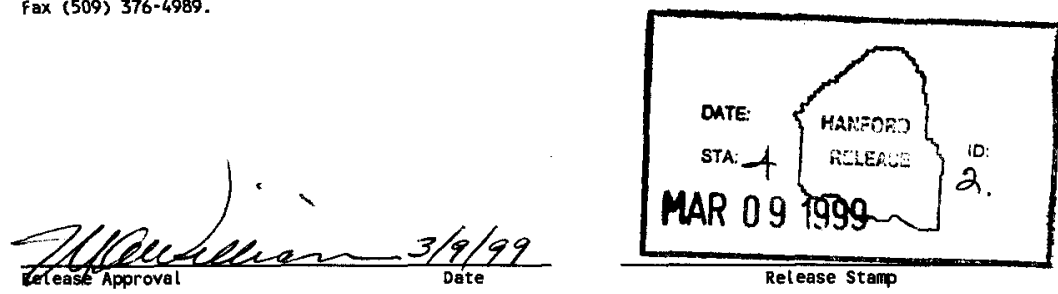

Approved for Public Release 
HNF-4099, Rev. 0 ULTRASONIC INTERFACE LEVEL ANALYZER SHOP TEST PROCEDURE

\section{TABLE OF CONTENTS}

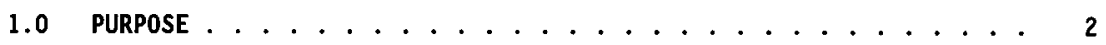

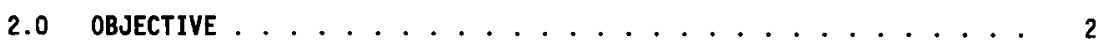

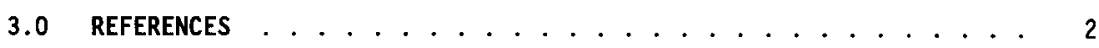

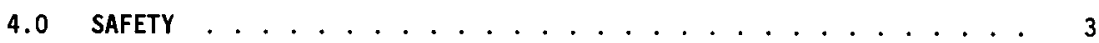

5.0 RESPONSIBILITIES ............................... 4

6.0 EQUIPMENT .............................. 4

7.0 EQUIPMENT REQUIRED FOR TESTING ............... 6

8.0 SHOP TEST . . . . . . . . . . . . . . . . . 6

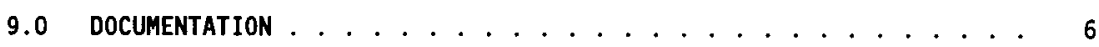

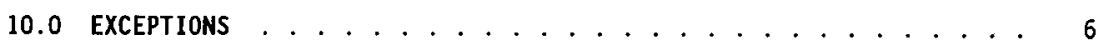

APPENDIX A ......................... 7

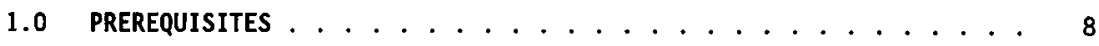

2.0 PROCEDURE ........................ 8 
HNF-4099, Rev. 0

\subsection{PURPOSE}

The Royce Instrument Corporation Model 2511 Interface Level Analyzer (URSILLA) system uses an ultrasonic ranging technique (SONAR) to measure sludge depths in holding tanks. Three URSILLA instrument assemblies provided by the $W-151$ project are $p 1$ anned to be used during mixer pump testing to provide data for determining sludge mobilization effectiveness of the mixer pumps and sludge settling rates.

The purpose of this test is to provide a documented means of verifying that the functional components of the three URSILLA instruments operate properly. Successful completion of this Shop Test Procedure (STP) is a prerequisite for installation in the AZ-101 tank.

\subsection{OBJECTIVE}

The objective of the test is to verify the operation of the URSILLA instruments and to verify data collection using a stand alone software program.

\subsection{REFERENCES}

\subsection{Drawings}

H-2-68327, Sh.l

H-2-68330, Sh. 2,4

H-2-68335, Sh. 7

H-2-68423, Sh. 1

H-2-78948, Sh. 7-9

$\mathrm{H}-2-78982$, Sh. 2

H-2-78983, Sh. 3,4

H-2-78984, Sh. 1,2

H-2-79212, Sh. $1,4,7,9$

H-14-100454, Sh. 1,2,3

H-14-100736, Sh. 1,2
Tank AZ-101 Elec./Inst. Equipment Wire Run List

Tank AZ-101 Elec./Inst. Equipment Wire Run List

IEFD Tank Farm

Tank Riser Air Lift Circulator Details

Elec./Inst. Equipment Interconnection

Diagram

Control Console AZ-101-156 Assembly

Console AZ-101-156 Wiring Diagram

Console AZ-101-156 Cable Assemblies

$\mathrm{Elec} /$ Instr/JB/Cnd Installation Tank AZ-101

UTtra Sonic Interface Level Analyzer Assemblies

Interconnection Diag UItrasonic Interface Analyzer Cabling 


\subsection{Vendor Information}

ROYCE instrument Corporation, Model 2511, Interfacce Level Analyzer Operators Manual, New Orleans, La., VIN 0022515, Supplement 041

ROYCE instrument Corporation, Model 2511, Interfacce Level Analyzer Profile Program Instructions, New Orleans, La., VIN 0022515, Supplement 041

\subsection{Other}

Flammable Gas Equipment Advisory Board Interpretation/ Recommendation Report, FGEAB-97-017, Rev. 2

Witwer, K. S., 1995a, Status on Royce Interface Level Detector, Internal Memo to G. T. Maclean, May 3, 1995.

Witwer, K. S., 1995b, Current Status and Results of Royce U1trasonic Sensor Testing, Memo to G. T. Maclean, September 19, 1995 .

Witwer, K. S., 1999, Report on Testing of the Royce Interface Level Analyzer, HNF-3782, Rev. 0, February 25, 1999, Numatec Hanford Company, Richland, Washington.

\subsection{Terms and Definitions}

$\begin{array}{ll}\text { INSTM } & \text { Instrument } \\ \text { PC } & \text { Personal Computer } \\ \text { STP } & \text { Shop Test Procedure } \\ \text { URSILLA } & \text { Ultrasonic Interface Level Analyzer }\end{array}$

\subsection{SAFETY}

Individuals shall carry out their assigned work in a safe manner to protect themselves and others from undue hazards and to prevent damage to property and the environment. Facility line managers shall assure the safety of activities within their areas to prevent injury, property damage, or interruption of operation. Performance of test activities shall always include safety and health aspects. 
HNF-4099, Rev. 0

\subsection{RESPONSIBILITIES}

\subsection{Test Director}

The Test Director is responsible for coordinating and directing the acceptance testing, and stopping or suspending the testing if there is a possibility of unsafe operations, damage to equipment, or injury to personnel.

\subsection{Test Engineer}

The Test Engineer will ensure that all necessary preparations for the ATP have been completed prior to beginning the test. The Test Engineer will initial completion of test steps and document test completion/ approval on the test acceptance page.

\subsection{Test Operator}

The Test Operator is responsible for performing the test under the direction of the Test Director, and providing equipment and instruments required to perform the test.

\subsection{Quality Assurance/Quality Control (QA/QC)}

The $Q A / Q C$ is responsible for witnessing the test, verifying completion of test sections, approving dispositions to test exceptions, and documenting completion/approval of the test on the test acceptance page.

\subsection{EQUIPMENT}

The Royce Instrument Corporation Model 2511 Interface Level Analyzer system consists of three main components - a sensor unit, an analyzer unit, and a data acquisition system. The system uses an ultrasonic ranging technique (SONAR) to measure the depth of sludge blanket interfaces within holding tanks. A small sensor mounted on the end of a $3 / 4 "$ diameter pipe is placed just under the surface of the liquid. An ultrasonic signal is sent and received through the sensor and forwarded by coaxial cable to the analyzer unit. The analyzer unit processes the information and provides a visual readout of the sludge/liquid interface layer(s) and/or tank bottom position. Specifics of the operation of the components are given below.

\subsection{Sensor Unit}

The sensing unit, Model 25MRA, is a 2" diameter by 3" long probe with a $1 / 4$ " thick outer shell made of carbon fiber/epoxy composite material. A piezoelectric crystal within the sensing unit acts as both a transmitter and receiver or "transceiver". Short $212 \mathrm{hz}$ bursts of ultrasonic energy 
HNF-4099, Rev. 0

transmitted from the crystal travel in a narrow beam towards the tank bottom and any resulting echoes are received in the same crystal.

The outer shell of the sensor is designed to withstand extreme environmental conditions such as high temperatures and very corrosive materials. Testing has also shown that there was no degradation of sensor performance after exposure to $5 \times 10^{6}$ RAD gamma radiation.

\subsection{Analyzer Unit}

The analyzer unit, Mode 12511 , measures the time delay and magnitude of the returning signals and stores this information in its memory in the form of a tank profile. The procedure is repeated several times to filter anomalous returns until an average "clean" profile is developed. The analyzer will adjust the power level of the transmitted signal based on the strength of returned signals. Several factors will influence the strength of the returned signals. The analyzer will attempt to adjust the power output to provide a signal return that will be easily distinguishable from the background noise. Once the profile is stored in memory, the analyzer can determine the depth of the interface, the depth of the tank bottom, and the depth of any "fluff" layers suspended above the interface. This information is then displayed both numerically and graphically on the front panel readout, or sent to a remote acquisition system where the same information can be displayed, manipulated and/or stored using vendor supplied software.

\subsection{Data Acquisition System}

A microcomputer is connected to the analyzer assembly via an RS232 serial interface. Data from the analyzer is then viewed using the software program provided by the vendor. The software enables the user to view and record data from the analyzer to disk as standard ascij test data. The data can be manipulated using other software such as spreadsheet or other programs. 
HNF-4099, Rev. 0

\subsection{EQUIPMENT REQUIRED FOR TESTING}

\subsection{Equipment required}

7.1.1 Items Provided:

- URSILLA assembly

- Operator PC and monitor

- Computer cable from PC to analyzer

- Software program

\subsubsection{Procured Items}

- Signal cable (temporary) from electronics box to analyzer, length as required (Ref. Dwg. H-14-100736, Sh. 1, Note 3.)

- Power cable (temporary) from power supply to analyzer, length as required (Ref. Dwg. H-14-100736, Sh. 1)

7.1.3 To Be Supplied by Test Facility

- Test tank, minimum height 6 feet

- Test simulant from sludge settlement testing

- Miscellaneous items for URSILLA assembly set up and electrical/instrument connections

\subsection{SHOP TEST}

The detailed steps of this Shop Test Procedure are provided in Appendix A. Approval signatures and associated data shall be recorded in the appropriate sections. A copy of the completed and approved test procedure will be incorporated into the Acceptance Test Report.

\subsection{DOCUMENTATION}

Editorial changes to this test procedure shall be by the redline method as determined and approved by the Test Director. Procedural and requirement changes must be processed on an Engineering Change Notice (ECN) in accordance with approved procedures. If a need for such a change is discovered in the course of running the test, the applicable portion of the test shall be stopped, and the test equipment shall be placed in a safe configuration, until the ECN is approved. However, this does not prevent the running of another portion of the test unaffected by the change.

\subsection{EXCEPTIONS}

Exceptions to the required test results shall be recorded and sequentially numbered on individual Exception forms (see figure 1). Actions taken to resolve the exceptions including retesting shall be documented and approved by the Test Director and QA/QC on the Exception Form. 
HNF-4099, Rev. 0

APPENDIX A

ULTRASONIC INTERFACE LEVEL ANALYZER SHOP TEST PROCEDURE 
HNF-4099, Rev. 0

\subsection{PREREQUISITES}

This procedure shall be performed for each of the three URSILLA instrument assemblies. This appendix can be copied for use for each URSILLA assembly. Prior to performing the test enter the unique URSILLA assembly number below.

URSILLA Assembly No.

\subsection{Test Set Up}

Assemble test equipment as follows: (See figure 2)

1.1.1 Install URSILLA assembly and test tank at test location.

1.1.2 Fill tank with test simulant. When the sludge has settled there should be a minimum of 4 feet of liquid supernatant between the sensor and the sludge layer.

1.1.2 Connect power cable to power source.

1.1.3 Connect signal cable wires from electonics box to analyzer.

1.1.4 Connect computer cable from analyzer to PC.

1.1.5 Load the Royce Tank Profile software program on the PC.

QA/QC sign below verifying test set up has been completed.

QA/QC Date

\subsection{PROCEDURE}

\subsection{URSILLA CONFIGURATION}

The following settings are required to be made in the URSILLA analyzer enclosure prior to operation.

2.1.1 Turn the power on/off switch to the ON position. When the unit is turned on for the first time, it will be in the alarm condition. A message will appear on the graphic panel that explains that the unit will not operate until the tank depth has been programmed. (If the unit does not give this error message, it means a non-zero tank depth value has already been stored. In this case, only the RUN 1 ight will light on the front panel.) 
2.1.3 Press the PGM key to enter the analyzer "program" mode of operation. The unit should display a HELP screen.

NOTE: For purposes of testing the installation, temporary program parameters will be entered to allow verification of connections.

2.1.4 Press the NEXT PAGE key to bring up the "DISPLAY FORMAT" help screen. Use the UP arrow key to select a value of 1 to display the depth of sludge in feet.

2.1.5 Press the NEXT PAGE key again to bring up the "ECHO PROFILE UPDATE RATE" screen. Use the arrow keys to select a value of 4 to have the URSILLA average a minutes worth of tank profiles.

2.1.6 Press the NEXT PAGE key again to bring up the "INTERFACE LEVEL AVERAGING CYCLES" screen. Use the arrow keys to select a value of 5 to average 5 profile groups.

2.1.7 Use the PREV PAGE key to scroll back to the "TANK DEPTH" screen. Enter a temporary tank depth in feet that is at least two feet deeper than the actual tank depth and record below.

Tank Depth feet.

2.1.8 Press the RUN key. The display will go blank for a minute or so while the unit attempts to adjust transmitter power to the condition of the tank. After this delay, an "echo profile" graph will appear in the LCD display. The numbers along the side of the graph indicate the depth in feet from the top of the tank. At each depth, the magnitude of the graph indicates the strength of the echo energy that is returning from that spot on the tank. At the very bottom of the graph, the unit will display a message to indicate the transmitter power (GAIN) that is being used to create this graph. Verify that there is at least one obvious bump in the graph (ignoring the one at the very top).

2.1.9 Examine the graph to see if the position of the tank bottom is apparent. The tank bottom should appear as a sharp peak in the graph at some reading above zero, depending on the value used in step 2.1.7. Enter the exact tank bottom position shown on the graph to the nearest tenth of a foot.

Tank Bottom Position feet. 
HNF-4099, Rev. 0

2.1.10 Press the PGM key to reprogram the URSILLA for normal operation.

2.1.11 Press the NEXT PAGE key to bring up the "DISPLAY FORMAT" help screen. Use the UP arrow key to select a value of 1 to display the depth of sludge in feet.

2.1.12 Measure the actual distance from the bottom of the sensor to the bottom of the tank.

2.1.13 Press the PREV PAGE key and enter the correct tank depth. The correct depth can also be obtained by subtracting the tank bottom position (step 2.1.9) from assumed tank depth from step 2.1.7.

2.1.14 Using the NEXT PAGE and arrow keys, set the parameters given in Table 1. Additional information on parameters are contained in the Operators Manual.

QA/QC sign below verifying URSILLA configuration requirements have been completed.

QA/QC Date

\subsection{URSILLA OPERATION TESTING}

2.2.1 Allow test simulant to settle such that there is a clear settled solids interface.

2.2.3 Measure the sludge depth (distance from the bottom of the tank to the top of the settled solids interface) and enter in Table 2.

2.2.1 Press the RUN key to begin operation. The analyzer display will be blank for approximately 10 minutes. After this time, both the numeric display (sludge depth) and the graphic profile (echo profile) will be updated once every minute.

2.2.2 Verify that the graphical profile readings and numerical sludge level are displayed at the URSILLA PC monitor

2.2.3 Read the sludge depth (blanket level) from the dispaly screen and enter the value in Table 2.

2.2.4 Mix tank contents until solids are fully mobilized. 
HNF-4099, Rev. 0

2.2.5 Allow solids to settle. Measure and record sludge depth and record URSILLA readings in Table 2 while the solids are settling at hourly intervals (minimum) for 5 hours. Sludge depth measurement should increase with each reading.

2.2.6 Press the NEXT PAGE key while the URSILLA is in the RUN mode. A trend graph should be displayed on the screen which shows the sludge interface height over time. Press the PREV PAGE key to return to the profile graph.

QA/QC sign below verifying URSILLA operation testing has been completed. QA/QC Date

\subsection{TEST APPROVAL AND ACCEPTANCE}

Testing of the URSILLA assembly per this shop test procedure is approved as follows:

Without exceptions

Test Engineer

$\overline{Q A} / Q C$

Date
With exceptions

resolved

$\overline{\text { Date }}$
With exceptions outstanding 
TABLE 1

\begin{tabular}{|c|c|c|}
\hline PARAMETER & VALUE & DESCRIPT ION \\
\hline Tank Depth & TBO & Depth from bottom of sensor to the bottom of the tank \\
\hline Display Format & 1 & Depth of sludge measurement will read in feet \\
\hline Irend Graph & 3 & Trend graph scale will span 12 hours \\
\hline Echo Profile & 4 & One minutes worth of echo profiles will be averaged \\
\hline $\begin{array}{l}\text { Interface Level } \\
\text { Averaging Cycles }\end{array}$ & 10 & Ten sets of profiles will be averaged \\
\hline Irigger Point & 1 & The biggest peak will be tracked \\
\hline Median or Average & 1 & Profiles will be averaged rather than taking the median \\
\hline Sensitivity & 8 & Smaller profiles will not be analyzed \\
\hline Bottom Dead Zone & 1 & Dead zone at the bottom of the tank will be $1 / 10$ foot \\
\hline Iop Dead Zone & 10 & Dead zone at the top of the tank will be 1 foot \\
\hline Gain Control & 0 & Transmitter power will be adjusted autonatically. \\
\hline $\begin{array}{l}\text { Botton Echo in } \\
\text { Gain Control }\end{array}$ & 0 & Transmitter power adjusted based on the size of tank botton peak \\
\hline $\begin{array}{l}\text { Speed of Sound } \\
\text { Correction }\end{array}$ & 1.000 & The speed of sound in the liquid wll be set to that of water \\
\hline $\begin{array}{l}\text { Lost Interface } \\
\text { Control }\end{array}$ & 1 & Alarm point to sound when no interface is detected \\
\hline Serial Address & 1 & Analyzer address \\
\hline Baud Rate & 9600 & Speed of date exchange between the computer and analyzer \\
\hline 4 mA Level & 2 & $\begin{array}{l}\text { Meter reading that will cause a } 4 \mathrm{~mA} \text { level at the current output } \\
\text { terminals }\end{array}$ \\
\hline $20 \mathrm{~mA}$ Level & 12 & $\begin{array}{l}\text { Meter reading that will cause a } 20 \mathrm{~m} \text { level at the current output } \\
\text { terminals }\end{array}$ \\
\hline $\begin{array}{l}\text { Relay Number } x \\
\text { Funct ion }\end{array}$ & 1 & Relays will activate for readings higher than the setpoint \\
\hline $\begin{array}{l}\text { Relay Number } x \\
\text { "ON" Setpoint }\end{array}$ & 1.9 & Trip point for when the high alarm is activated \\
\hline $\begin{array}{l}\text { Relay Number } x \\
\text { "OfF" Setpoint }\end{array}$ & 1.9 & Trip point for when high alarm is turned of $f$ \\
\hline
\end{tabular}


HNF-4099, Rev. 0

TABLE 2

\begin{tabular}{|l|l|l|l||}
\hline & $\begin{array}{l}\text { Measured } \\
\text { Sludge Depth } \\
\text { (feet) }\end{array}$ & $\begin{array}{l}\text { Sludge depth } \\
\text { from URSILLA } \\
\text { display (feet) }\end{array}$ & $\begin{array}{l}\text { Difference in } \\
\text { Readings }\end{array}$ \\
\hline & & & \\
\hline & & & \\
\hline & & & \\
\hline & & & \\
\hline & & & \\
\hline & & & \\
\hline & & & \\
\hline & & & \\
\hline & & & \\
\hline
\end{tabular}


Figure 1

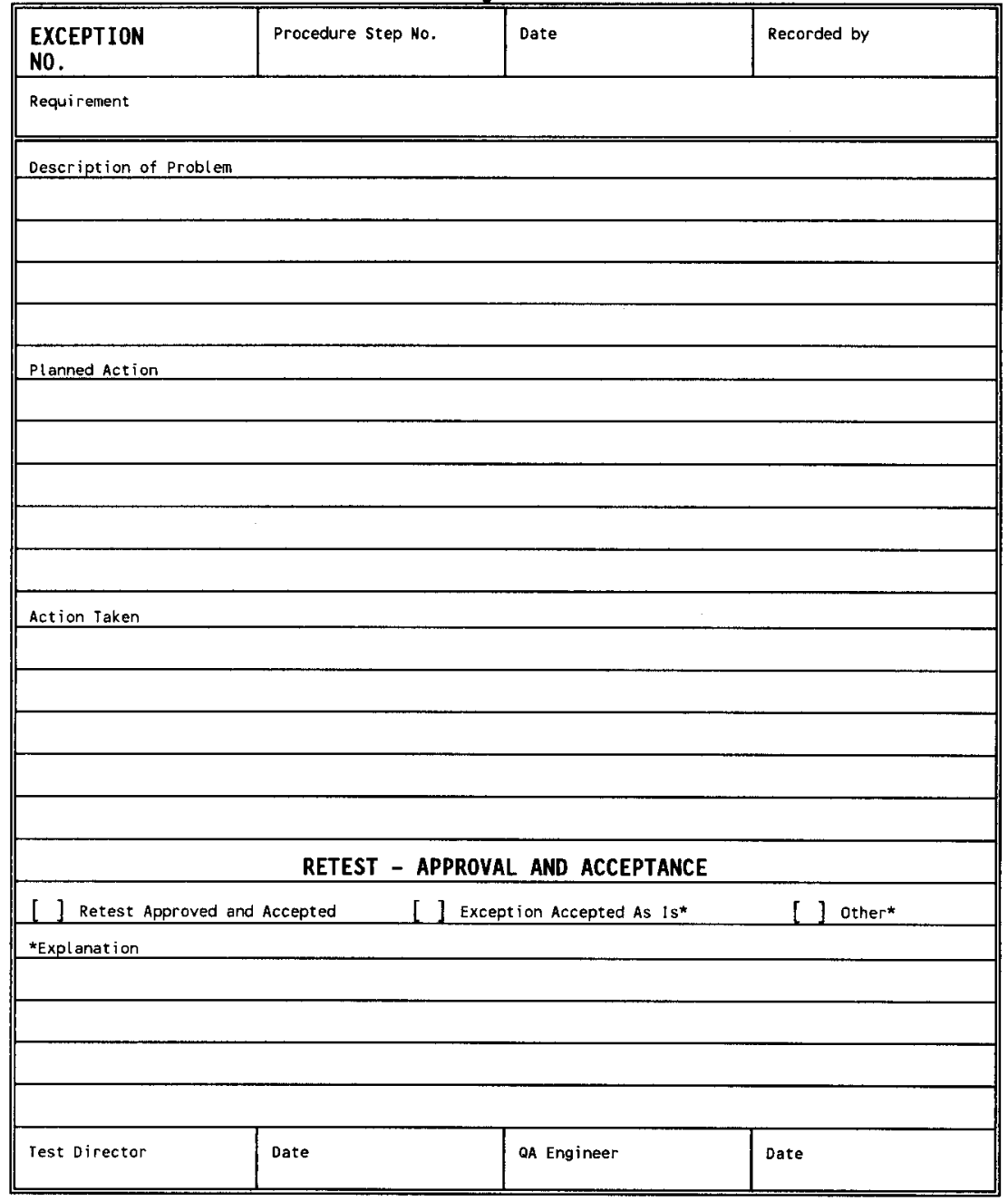


HNF-4099, Rev. 0

FIGURE 2

\section{ULTRASONIC INTERFACE LEVEL ANALYZER \\ (URSILLA)}

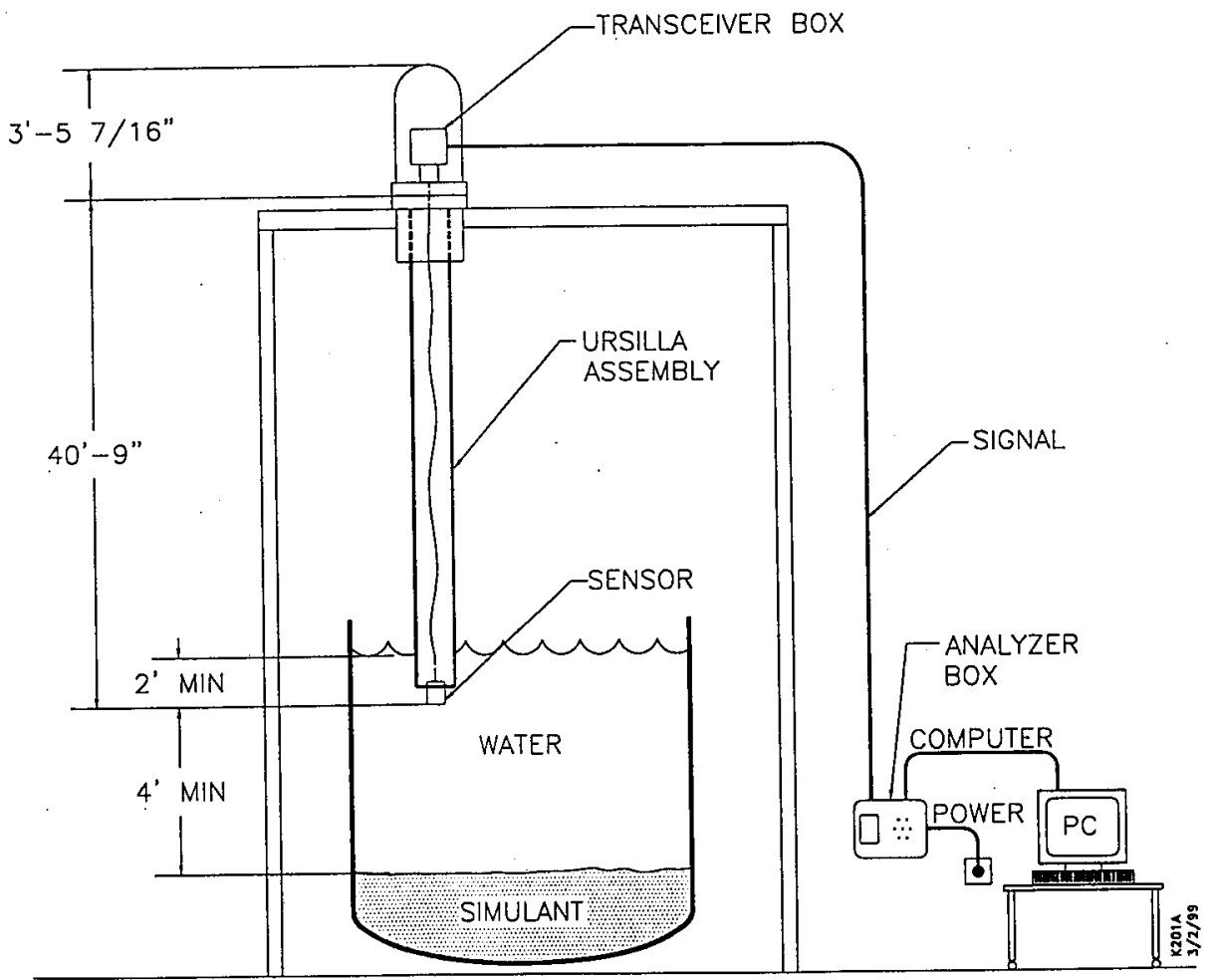

